Journal of the Egyptian Society of Parasitology, Vol.43, No.1, April 2013

J. Egypt. Soc. Parasitol., 43(1), 2013: 71 - 86

\title{
ANTIVIRAL IMMUNITY IN THE RED SWAMP CRAYFISH, PROCAMBA- RUS CLARKII: HEMOCYTE PRODUCTION, PROLIFERATION AND APOPTOSIS
}

By

\author{
ABDEL-HAKIM S. EL-DIN, KOHAR G. VARJABEDIAN, \\ REWAIDA A. ABDEL-GABER AND MARWA M. MOHAMED
}

Department of Zoology, Faculty of Science, Cairo University, Cairo, Egypt

\section{Abstract}

In the present study, the pathogenic mechanism of white spot syndrome (WSSV) in crayfish, Procambarus clarkii by investigating activities of immune cells related to innate immune function during infection was explored. White spot disease caused by WSSV leads to devastating losses in crayfish farming. Examination by transmission electron microscopy revealed abundant WSSV particles and significant changes in the different lymphoid organs of infected crayfish. WSSV infection caused parts of the gill epithelium and microvilli to be reduced in number and size or damaged, meanwhile, the mitochondria, morphology changed, with parts of the cristae diminished leaving large vacuoles. Moreover, electron dense deposits appeared and hetero-chromatinized nuclei could be seen in blood cells with ruptured nuclear membranes and outflow of nucleoplasm. Also, evident were very densely basophilic inclusions were found in interstitial hepato-pancreatic tissue, connective tissue underlying the mid gut, cardiac tissue, gill tissue and hematopoietic tissue. Transmission electron microscopy revealed the presence of previously undescribed rod-shaped, enveloped versions in the cytoplasm adjacent to the nuclei of cells from various tissues.

Correspondence: E-Mail: rewaida85@yahoo.com

Keywords: Procambarus clarkii; White spot syndrome virus (WSSV); Apoptosis; Antiviral immunity; VP28; Lymphoid organs; Histological alterations; Ultrastructure.

\section{Introduction}

Freshwater crayfish, Procambarus clarkii, is a crustacean belonging to order Decapoda, family Parastacidae. It is one of the most important commercially farmed crayfish in the world due to its many advantages, including po- lyphagia, fast growth and easy culture, as well as being rich in protein and low in cholesterol (Mu et al, 2007). During the last two decades, the environmental and health problems in crayfish culture have resulted in the outbreak infectious diseases with the constancy expanding scale of aquaculture and rapid develop- 
ment of intensive culture techniques of $P$. clarkii in Egypt. The worldwide shrimp/crayfish culture industry for been beset with diseases mainly caused by viruses, particularly with white spot syndrome virus (WSSV), and has suffered significant economic losses.

White spot syndrome virus (WSSV) is currently the major viral pathogen of aquaculture shrimps (Escolbedo-Bonilla et al, 2008; Liang et al, 2010) and has a broad host range, including marine and freshwater crustaceans (Wang et al, 2011). WSSV is an enveloped, large circular double standard DNA virus containing approximately 300 Kbp (Yang et al, 2001; Chen et al, 2002) and classified into genus Whisprovirus of the new family Nimaviridae virus Family (Marks et al, 2005; Escobedo-Bonilla et al, 2008). Although studies on the epidemiology and prevention of WSSV as well as virus detection have been performed (Shi et al, 2000; Rachel et al, 2002; Claydon et al, 2004; Unzueta-Bustamante et al, 2004; Hao et al, 2009), detailed analysis of immunological variables and the mechanism of resistance to WSSV in P. clarkii have not been reported.

Effects of primary physico-chemical changes and environmental pollutants in immuno-regulatory studies of decapod crustaceans have been reported by many scientists and reviewed by Le Moullac and Haffner (2000) and Cheng and Chen (2002). Intrinsic factors such as sex, size, moult stages and nutritional status have been reported to affect the immune system in several species of penaeids including $P$. monodon (Owens and O'Neill, 1997) Marsupenaeus japonicus (Tsing et al, 1989) and blue shrimp Litopenaeus stylirostris (Le Moullac et al, 1997). Also, the number of hemocytes within a decapod crustacean varies with the moult cycle. The phenomenon has been documented in M. japonicus (Tsing et al, 1989), $L$. Stylirostris (Le Moullac et al, 1997) and L. vannomei (Liu et al, 2004). Viral structural proteins, especially the envelope proteins, are important, not only because they are involved in virion morphogenesis, but also because they are the first molecules to interact with the host. The envelope protein Vp28 is the most abundant envelope protein located on the surface of WSSV and is likely to play a key role in the initial steps of the systemic virus infection in shrimp (Van Hulten et al, 2001). Another study showed that recombinant Vp28 protein (rVP28) can produce protective immunity against experimental WSSV challenge in shrimp (Witterveldt et al, 2004).

Generally, crustaceans have an innate immune system, which comprises cellular and humoral response. The cellular immune response mainly include apoptosis, phagocytosis and encapsulation, whereas humoral responses primarily include the prophenol-oxidase (ProPh) system, reactive oxygen intermediates (ROIs) and a wide array of antimicrobial peptides. Other studies indicated that apoptosis is proposed as the main anti-viral non-specific defense mechanism in crustaceans ( $\mathrm{Wu}$ and Moraga, 2004; Fu et al, 2010). 


\section{Materials and Methods}

Experimental animals: Out of 200 red swamp crayfish (Procambarus clarkii) were brought form Mansouria Canal, Giza Governorate during spring and rose in $120 \mathrm{~L}$ glass tank. After 7 days acclimatization to the new environment, ten crayfish were randomly selected to detect whether they were infected with WSSV using PCR via the primer Vp28 F and Vp $25 \mathrm{R}$ (Tab. 1) which were designed from the $\mathrm{Vp} 28$ sequence.

Collection of tissues: After anaesthetizing the crayfish by soaking them in ice for $15 \mathrm{~min}$, hemolymph was harvested using an ice-cold anticoagulant buffer $(0.14 \mathrm{M} \mathrm{Nacl,} 0.1 \mathrm{M}$ glucose, $30 \mathrm{mM}$ trisodium citrate, $26 \mathrm{mM}$ citric acid, and 10mM EDTA, pH 4.6) (Soderhall and Smith, 1983). After centrifugation at $800 \mathrm{xg}$ for $10 \mathrm{~min}\left(4^{\circ} \mathrm{C}\right)$, the hemocytes were isolated and the cellfree hemolymph was obtained. Subsequent to the collection of hemolymph, tissues including the heart, hepatopancreas, gills and stomach for further studies.

Histopathological examination by light microscopy: The collected crayfish were fixed with Davidson's fixative for paraffin sectioning. Sections were stained with hematoxylin and eosin, as described in Bell and Lightner (1985). All organs are examined at 100-1000x magnification by using the Olympus Dp50 Microscope Digital Camera System.

Transmission electron microscopy: The LO of both WSSV-infected and control animals was dissected and fixed for $24 \mathrm{~h}$ in 3\% glutaraldehyde and in $0.2 \mathrm{M}$ sodium cacodylate buffer ( $\mathrm{pH}$ 7.4). The tissue was washed twice in $0.1 \mathrm{M}$ sodium cacodylate buffer, post-fixed in $1 \% \mathrm{OsO}_{4}$ for an h, dehydrated and embedded in Epon 812. After cutting, the ultrathin sections were mounted on copper grids, counterstained in uranyl acetate and lead citrate and examined using a Philips 208 TEM.

Multiple PCR was used for amplification. PCR mixture $(50 \mathrm{~mL})$ contained $0.5 \mathrm{~mL}$ DNA polymerase $(0.25 \mathrm{U})$ (Promega, USA), $10 \mathrm{~mL}$ primer mixture $5 \mathrm{~mL} \mathrm{10x}$ Tag buffer (including $\mathrm{Mg}^{+2}$ ), $2 \mathrm{~mL}$ dNTP, $5 \mathrm{~mL}$ DNA templates and $27.5 \mathrm{~mL}$ sterile water. According to the thermocycler (PTC-100; Bio Rad, USA) manufacture's instruction, the amplification cycle protocol as follow: $3 \mathrm{~min}$ at $94^{\circ} \mathrm{C}$, then 35 cycles of $1 \mathrm{~min}$ denaturation at $94^{\circ} \mathrm{C}, 1 \mathrm{~min}$ of annealing at 55 on $59^{\circ} \mathrm{C}$, and $1.5 \mathrm{~min}$ extension at $72^{\circ} \mathrm{C}$, followed by a final extension step of $10 \mathrm{~min}$ on $72^{\circ} \mathrm{C}$. PCR products were analyzed by agarose gel electrophoresis using 2\% agarose gel in presence of a standard molecular size ladder, followed by UV visualization after ethidium bromide staining. PCR products were separated on agarose gel and purified using an Easy Pure Quick Gel Extraction kit (Cal Biochem, Nottingham, UK).

Construction of vector Plevp 28: A $146 \mathrm{bp}$ fragment, including $23 \mathrm{bp}$ critical fragment of the Le1 promoter of WSSV, with primers Le1F and ie1R (with Bgl II and Sal I restriction enzyme sites) (Tab. 1) were obtained 
from WSSV genome. The full length of the Vp28 was also cloned with the primers $\mathrm{Vp} 28 \mathrm{dmF}$ and $\mathrm{Vp} 28 \mathrm{dmR}$ (with Sal 1 and Pst 1 restriction enzyme sites).

WSSV preparation: The WSSV viral particles were obtained from tissues (e.g. gill, stomach...etc.) of diseased shrimp-with spot syndrome using the method of Xie et al. (2005). The WSSV viral particles were stable at $70^{\circ} \mathrm{C}$. Competitive PCR was developed to measure the exact number of WSSV genome. This method is based on competitive co-amplification of a target WSSV genome together with known concentrations of an internal standard in a one-tube reaction (Tang and Lightner, 2000).

Total nucleic acid purification: The abdominal muscles from $P$. clarkii were collected from crayfish. Approximately $1.0 \mathrm{~g}$ of abdominal muscle was excised from each specimen, were cut into small pieces and homogenized on ice in a Potter-Elvehjem tissue grinder at $8000 \mathrm{~g}$ with $600 \mathrm{ml}$ chilled lysis buffer $\left(100 \mathrm{mmol}^{-1} \mathrm{Nacl}, 10 \mathrm{mmol}^{-1} \mathrm{ED}-\right.$ TA, $50 \mathrm{mmol}^{-1}$ Tris base, $0.5 \%$ SDS, $\mathrm{pH} 7.5$ ), transferred to a new $1.5 \mathrm{ml}$ centrifuge tube and treated with $1.5 \mathrm{~mL}$ proteinase $\mathrm{K}$ (Merck, Denmark) stock solution $\left(20 \mathrm{mg} \mathrm{ml}^{-1}\right)$. After incubation at $65^{\circ} \mathrm{C}$ for $30 \mathrm{~min}$, the samples were immediately chilled on ice bath for 5min, subsequently; $200 \mathrm{mmol}^{-1}$ $\mathrm{NH}_{4} \mathrm{OAC}$ was added and mixed, then centrifuged at $12000 \mathrm{~g}$ for $10 \mathrm{~min}$ at $4^{\circ} \mathrm{C}$. $650 \mathrm{ml}$ aliquot of the supernatant was transferred to a new $1.5 \mathrm{ml}$ tube, and $700 \mathrm{~mL}$ chilled isoproparnol was added to the tube. The mixture was inverted several times and placed at $20^{\circ} \mathrm{C}$ for $30 \mathrm{~min}$ and then centrifuged at $12000 \mathrm{~g}$ for $10 \mathrm{~min}$ at $4^{\circ} \mathrm{C}$. The resulting pellet was rinsed twice with 500 $\mathrm{mL} 75 \%$ chilled ethanol and then air dried for $15 \mathrm{~min}$. The total nucleic acid pellet was resuspended in $100 \mathrm{ml}$ of sterilized water at $65^{\circ} \mathrm{C}$ for $10 \mathrm{~min}$ and stored at $20^{\circ} \mathrm{C}$ until used.

Oligonucleotide primers: Two specific primers sets were used in the multiplex PCR, including the following: 94F2-WSSV/94R2-WSSV for WSSV and ITS-crayfish/28S-crayfish for the internal control in the $P$. Clarkii experiment (Tab. 1). The primer set ITS crayfish/28S-crayfish was designed using primer Premier V5.0 (Premier Bio-soft International, Palo AHO, CA, USA) from the Internal Transcribed Spacer 2 (ITS-2) and 28S RNA sequences of $P$. clarkii, based on published sequences available in the Gene Bank under Accession No. GQ369797 (http://www.ncbi.nlm.nih.gov/nuccore/ 255964841).

Table 1: Sequence of the primer used in this study

\begin{tabular}{|l|l|l|}
\hline Primer & Sequence $\left(5^{\prime}-3^{\prime}\right)$ & Direction \\
\hline Le 1 promotor $\mathrm{F}$ & TACTCAAGATCTACCACCCCT & Forward \\
\hline Le 1 promotor R & TACTCAGTCGACCTGAGGA & Reverse \\
\hline VP $28 \mathrm{dm}$ F & TACTCAGTCGACACCAT & Forward \\
\hline VP $28 \mathrm{dm}$ R & TACTCACTGCAGTTACT & Reverse \\
\hline $18 \mathrm{~S}$ rRNA F & TCTTCTTAGAGGGA & Forward \\
\hline 18 S rRNA R & AAGGGGATTGAA & Reverse \\
\hline
\end{tabular}




\section{Results}

$P$. clarkii infected with WSSV: The body surface of infected $P$. clarkii showed apparent symptoms, no obvious white dots could be seen on the cephalothorax, abdominal crusta or appendages but they stopped feeding and displayed slow reaction and weak chelicerae during the later stage. The hemolymph of $P$. clarkii which were close to dying could not be solidified and was slightly red in color. In addition, the infection caused the cephalothorax to be early separated and the podities to break, the gills to slightly puff up and coloring of the hepatopancreas to be yellowish. Meanwhile, the control group was all alive with no abnormal symptoms. However, the WSSV infected crayfish all died generally within 3-5 days. Among the dead crayfish in infected group, 10 randomly sampled animals that were tested for WSSV infection by PCR were $100 \%$ WSSV positive.

The localization of Vp28: The Vp28 was detected using western blotting with anti-Vp28 polyclonal antibodies. The results show that Vp28 can be detected in the hemolymph, hemocytes, hepato-pancreas, gills, stomach and intestine of the non-infected control (Fig. 1A). In WSSV-infected crayfish, a much stronger signal was observed mainly in the hemolymph and hemocytes (Fig. 1B). This means that the Vp28 could be released and binds to the membrane of hemocytes and protects crayfish from WSSV by blocking the binding site of virus.

The histopathological examination showed the principal lesions of $\mathrm{Vp} 28$ in the crayfish were cell swelling, vacuolar degeneration, necrosis and hepato-pancreatic epithelia and myocardial cells were the major target cells causing mortality (Fig. 2). During WSSV infection, brownish nuclei representing fragmented DNA were often observed in cells of stomach, gut and hepatopancreas, but there were few cells in negative control (Fig. 3). The occurrence of apoptosis was further confirmed by TEM, and the signs of apoptosis (chromatin condensation and nuclear fragmentation, as well as formation of apoptotic bodies) could be observed (Fig. 4).

Effects of WSSV infection on gills of $P$. clarkii: In healthy $P$. clarkii, the gills appeared normal (Fig. 5A) except for the presence of distinct partitioned areas of vacuolated cells containing hypertrophied nuclei (spheroid bodies). WSSV-infected crayfish revealed extensive cellular necrosis, loss of defined tubule structure and tubule lumen occlusion (Fig. 5B) WSSV was detected throughout the gills, both in areas where tubule structure had been lost (Figs. 5A,B) and within intact tubules (Fig. 5C). When spheroids present, cells within their structures was detected throughout the stromal matrix (Fig. 5A) or restricted to cells at the periphery of the tubules and adjacent to the central lumen (Figs. 5B,C). A cellular necrosis was observed in the central axes and the epithelial pillar cells of the primary and secondary filaments of the gills (Fig. 5D), and in some cases associated with the necrosis 
and fusion of the filament tips.

At Ultrastructural level: The cuticle of control P. clarkii gill leaves showed dense outer and inner electron density layers. The top of the tightly packed border microvilli formed from the apical membrane of epithelial cells contacted the inner cutin membrane, while the base of the microvilli was fairly regular over the cutin space (Fig. 6A). Epithelial cells were filled with round or sausage shaped mitochondrial (Fig. 6B). The mitochondrial matrix was dense and the mitochondrial cristae packed tightly. In addition, the nuclear membrane was complete and the nuclear chromatin was evenly distributed (Fig. 6B). However, WSSVinfected group had significant change in the fill ultrastructure. The electron density of the cutin membrane was uneven. The epithelial cell bodies were incomplete, with the apical membrane combined with the cuticle (Fig. 6C). The cells were separated from the epithelial layer, leaving a large space between the cutin and epithelium (Fig 6D).

Effects of WSSV infection on lymphoid organs: Chronically WSSVinfected lymphoid organ was still covered by a complete capsule bearing the antennal tubules. Within the tubules, lymphoid tubules were disorganized and had lost the normal appearance, and parts of the tubules lymphoid spheroids that lack a lumen (Fig. 7). When compared to the normal lymphoid organ could be classified into three type, Spheroid type 1 (Fig. 7A) was a lightly basophilic, homogenous mass, cells in the spheroid contained hypertrophic nuclei with few or no cytoplasmic vacuoles. Spheroid type 2 (Fig. 7B) appeared more basophilic in staining, and was fully encapsulated with a fibrous connective sheets and a layer of cells with flat nuclei. There were increased numbers of apoptotic cells that contained intensely basophilic nuclei and a moderate number of cytoplasmic vacuoles. Spheroid type 3 (Fig. 7C, D) contained the most basophilic cells and was encapsulated by thick fibrous connective tissue.

At the ultrastructural level: Spheroid type 1 contained degranulated small granular hemocytes surrounding the stromal cells (Fig. 8). Spheroid type 2 was paler blue when compared to spheroid type 1 (Fig. 8). There were increasing number of hypertrophic and apoptotic cells in spheroid type 2 (Fig. 9). Spheroid type 3 was a degenerating mass with mostly vacuolated apoptotic cells (Fig. 10).

\section{Discussion}

Crayfish, like other crustaceans, do not possess an adaptive immune response, but rely primarily on innate immune system including the hemolymph coagulation system (Yeh et al, 1998, 1999), the production of antibacterial peptides (Destoumieux et al, 1997), anti-lipopolysaccharide factor (Somboonwiwat et al, 2005) and the melanization reaction through the production of prophenol oxidase system (Perazzolo and Barracco, 1997: Soderhall et al, 1991; Sritunyalucksana et al, 2006) to respond to bacterial or fungal infections. These mechanisms prevent 
the spread of these pathogens to the body and mediated by circulating hemocytes in the hemolymph. Other studies showed that the lymphoid organs is a major organ which contains exocytosed, granular cells that have phagocytosed foreign materials, particularly the viruses, suggesting that the lymphoid organ constitute a major site for penaeid antiviral defense (Hasson et al, 1999; Anggraeni and Owens, 2000).

Apoptosis is essential in both the development and homeostasis of multicellular organisms. It still might be the main anti-viral mechanism in invertebrate (Clem and Miller, 1993). It has been demonstrated that apoptosis is the major symptoms induced in shrimp infected by WSSV (Wongpraser et al, 2003). But, whether it is a factor leading to shrimp mortality or can help the shrimp to survive the infection is still controversial. For example, some studies suggested that apoptosis is part of the anti-viral response to protect the shrimp from WSSV in $P$. vannosmei and $P$. japanicus (Granja et al, 2003; Wang et al, 2008). Another research thought that apoptosis did not play an important role in survival of WSSV challenged $P$. japanicus (Wa and Moroga, 2004). In addition, the highly virulent WSSV isolate, infected mainly the epithelium of the stomach, gut and hepato-pancreas (Wei and $\mathrm{Xu}, 2009$; Wei and Tang, 2011).

In the present study, only WSSV infected crayfish were selected for the histopathological study in order to make sure that any changes that occurred would be in response to a single species of virus. This was ascertained by the rigorous diagnosis of WSSV infection with nested RT-PCR. Furthermore, VP 28 envelop glycoprotein was detected specifically in cells within the wall of lymphoid tubules as well as lymphoid spheroids. The most obvious changes in the organization of the lymphoid organ of the chronically WSSV-infected crayfish were the presence of numerous lymphoid spheroids (LS) that were found during the course of infection. Vascular costs of the infected lymphoid organs showed that the terminal lymphoid tubules (LT) were drastically shortened and brunching of LT was not as elaborate as normal LT. In many instances only the relatively large stumps of the terminal LT remained. Furthermore, observation by light microscopy of a large area indicated that the lumen in the distal end of LT was obliterated and this end might breakdown thus shortening the original LT. The formation of LS in penaeid shrimp has been previously studied in P. vannamei (Hasson et al, 1999) and in P. monodon (Anggraeni and Owen, 2000). These authors observed the presence of three types of spheroidal masses after infection and proposed that they played roles in sequestering and finally eliminating virus.

\section{Conclusion}

WSSV is one of the most virulent disease agents so far reported for $P$. clarkii, and that it poses a dire threat to the aquaculture industry for this species. It may also be a threat to other species of the commercially cultivated 
crustacean. Thus, there is an urgent need to carry out further investigations concerning its basic characterization, infectivity, epizootiology, and viability under various conditions. Only then will be able to develop a rational program to control the disease and limit its spread.

\section{References}

Anggraeni, MS, Owens, L, 2000: The haemocytic origin of lymphoid organ spheroid cells in the penaeus prawn Penaeus monodon. Dis. Aquat. Org. 40:85-92.

Bell, T, Lightner, D.V, 1985: A Handbook of Normal Penaeid Shrimp Histology. World Aquaculture Society, Allen Press, Kansas.

Chen, J, Dai, W, Yu, C, Wang, H, Lo, C, et al, 2002: Transcriptional analysis of the DNA polymerase gene of shrimp white spot syndrome virus. Virol. 301:136-47.

Cheng, W, Chen, JC, 2002: The virulence of Enterococcus to freshwater prawn $\mathrm{Ma}$ crobrachium rosenbergii and its immune resistance under ammonia stress. Fish Shell-fish Immunol. 12:97-109

Claydon, K, Cullen, B, Owens, L, 2004: OIE white spot syndrome virus PCR gives false positive results in Cherax quadricarinatus. Dis. Aquat. Org. 62, 3:265e8

Clem, RJ, Miller, LK, 1993: Apoptosis reduces bath the in vitro replication and in vivo infectivity of a baculovirus. J. Virol. 67:3730-8.

Destoumieux, D, Bulet, P, Loew, D, Van Dorsselaer, A, Rolfiguez, J, et al, 1997: penaeidins, a new family of anti-microbila peptides isolated from the shrimp Penaeus vannamai (Decapoda). J. Biol. Chem. 272:28398-406.

Escolbedo-Bonilla, CM, Alday-San zv, Wille, M, Sorgeloos, P, Pensaert, MB, Nauwynck, HJ, 2008: A review on the morphology, molecular characterization, morphogenesis and pathogenesis of whit spot syndrome virus. J. Fish Dis. 31:1-18.

Granja, CB, Aranguren, LF, Vidal, OM, Aragón, L, Salazar, M, 2003: Does hyperthermia increase apoptosis in white spot syndrome virus (WSSV)-infected $\mathrm{Li}$ topenaeus vannamei? Dis. Aquat. Org. 54: 73-8.

Hao, GJ, Shen, JY, Xu, Y, Chao, Z, Pan, XY, 2009: Preparation of monoclonal antibodies against WSSV and application to test the virus in red claw crayfish. J. Jimei Univ. (Nat. Science) 14, 2:120e5.

Hasson, KW, Lightner, DV, Mohney, L L, Redman, RM, White, BM, 1999: Role of lymphoid organ spheroids in chronic Taura syndrome virus (TSV) infection in Penaeus vannamei. Dis. Aquat. Org. 38: 93-105.

Le Moullac, G, Haffner, P, 2000: Environmental factors affecting immune response in Crustacea. Aquaculture 191:12131 .

Le Moullac, G, Le Groumellec, M, Ansquer, D, Froissard, S, Levy, P, 1997: Haematological and phenoloxidase activity changes in the shrimp Penaeus stylitostris in relation with the moult cycle protection against vibriosis. Fish Shell-fish Immunol. 8:227-234.

Liang, TH, Lian, I, Wu, T, Gu, W, Wang, W, 2010: A rapid assay for simul- 
taneous detection of Spiroplasma eriocheiris and white spot syndrome virus in Procambarus Clarkii by multiplex PCR. Letter Appl. Microbial. 51:532-8.

Liu, H, Jiravanich, P, Soderhall, I, Cerernius, I, Soderhall, K, 2004: Anti-lipopolysaccharide factor interferes with white spot syndrome virus replication in vitro and in vivo in the crayfish Pacifastacus leniusculus. J. Virol. 80:10365-73.

Marks, H, Vorst, O, van Houwelingen, AM, van Hult, MC, Valk, JM, 2005: Gene expression profiling of white spot syndrome virus in vivo. J. Gen. Virol. 86: 2081-100.

Mu, F, Cheng, YX, Wu, XG, 2007: Distribution and industrial development of crayfish in the world. J. Shanghai Fisheries Univ. 16, 1:64-72.

Owens, L, O'Neill, A, 1997: Use of clinical cell flow cyclometer differential count of prawn Penaeus monodon haemocytes. Dis. Aquat. Org. 31:147-53.

Perazzolo, LM, Barracco, MA, 1997: The prophenoloxinase activating system of the shrimp Dev. Comp. Immunol. 21:38595.

Rachel, OB, Max, W, Andrew, F, Kelly, MLC, Angela, R, et al, 2002: A parvolike virus in cultured red claw crayfish Cherax quadricarinatus from Queensland, Australia. Dis. Aquat. Org. 50, 2:79e86.

Shi, Z, Huang, C, Zhang, J, Chen, D, Bonamu, JR, 2000: White spot syndrome virus (WSSV) experimental infection of the fresh water crayfish, Cherax quadricarinatus. J. Fish Dis. 23, 4:285-8.
Soderhall, I, Bangyeckhun, E, Mayo, S, Soderahll, K, 1991: Hemocyte production and maturation in an invertebrate animal, proliferation and gene expression in hematopoietic stem cells of Pacifastaecus leniusculus, Dev. Comp. Immunol. 27:661-72.

Soderhall, K, Smith, UJ, 1983: Separation of haemocyte populations of Carcinus maenas and then marine decapods, and prophenoloxidase distribution. Dev. Comp. Immunol. 7:229-39.

Somboonwiwat, $\mathrm{K}$, Marcos, M, Tassanakajon, A, Klinbunga, S, Aumelas, A, et al, 2005: Recombinant expression and anti-microbial activity of anti-lipopolysaccharide factor (ALF) from the black tiger shrimp Penaeus monodon. Dev. Comp. Immunol. 29, 10:841-51.

Sritunyalucksana, K, Wannapapho, W, Lo, CF, Flegel, TW, 2006: $\mathrm{Pm}-\mathrm{Rab} 7$ is a VP28-binding protein invo- lved in white spot syndrome virus infection in shrimp. $\mathrm{J}$. Virol. 80:10734-42.

Tang, KFJ, Lightner, DV, 2000): Quantification of white spot syndrome virus DNA through a competitive polymerase chain reaction. Aquaculture 189, 1e2:11e21.

Tsing, A, Arcier, JM, Brèhèlin, M, 1989: Haemocytes of penaeids and palaemonid shrimps: morphology, cytochemistry and hemograms. J. Invert. Pathol. 53:64-77.

Unzueta-Bustamante, ML, Silveira-Cofficny, R, Prieto, AA, Aguirre-Guzmán, G, Vázquez-Juárez, R, 2004: Susceptibility of Litopenaeus schmitti and Cherax quadricarinatus to white spot syndrome virus (WSSV). Ciencias Marinas 30, 4: 537e54. 
van Hulten, MC, Witteveldt, J, Snippe, M, Vlak, JM 2001b: White spot syndrome virus envelope protein VP28 is involved in the systemic infection of shrimp. Virol. $285,228-33$.

Wang, JX, Sun, C, Xu, WT, Zhang, HW, Dong, LP, et al, 2011: An anti-lipopolysaccharide factor from red swamp crayfish, Procambarus clarkii, exhibited antimicrobial activities in vitro \& in vivo. Fish Shell-fish Immunol. 30:295-303.

Wang, Z, He, W, Xu, W, 2008: Study on epidemic outbreak of disease of crawfish caused by WSSV. Chin. J. Hlth. Lab. Technol. 8:1397-9.

Wei, KO, Xu, ZR, 2009: Effects of oral recombinant up expressed in silk worm (Bombyx mori) pupa on immune response and disease resistance of Procambrus clarkia world J. Microbiol. Biotechnol. 8; 25:1321-8.

Witteveldt, J, Cifuentes, CC, Vlak, JM, van Hulten, MC, 2004: Protection of Pen- naeus monodon against white spot syndrome virus by oral vaccination. J. Virol. 78:2057-61.

Wongprasert, K, Sangsuriya, P, Phongdara, A, Senpin, S, 2003: Cloning and Characterization of a caspase gene from black tiger shrimp (Penaeus monodon) infected with white spot syndrome virus (WSSV). J. Biotechnol. 131:9-19.

Xie, XX, Li, HY, Xu, LM, Yang, F, 2005: A simple and efficient method for purification of intact white spot syndrome virus (WSSV) viral particles. Virus Res. 108:637.

Yang, F, He, J, Lin, X., Li, Q, Pan, D, et al, 2001: Complete genome sequence of the shrimp white spot bacilliform virus. J. Virol. 75:11811-20.

Yeh, M, Chen, YL, Tsai, IH, 1998: The hemolymph clottable proteins of tiger the shrimp, Penaeus monodon, and related species. Comp. Biochem. Physiol. 121: 169-76.

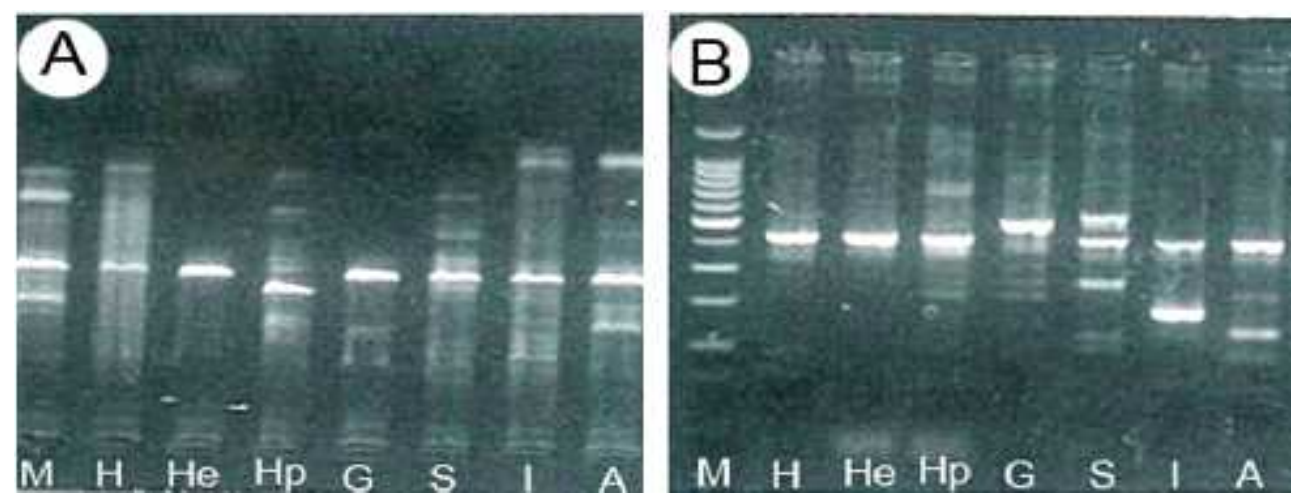

Fig. 1: Tissue distribution of Vp28 at the mRNA level. Transcript of inhibitor examined by semiquantitative PCR. Bottom panel indicates 18sRNA amplified as an internal control. (A) Non-infected animal. (B) WSSV-infected animal. M: Marker, H: hemolymph, He: heart, Hp: hepato-pancreas, G: gills, S: stomach, I: intestine, A: antennal gland. 


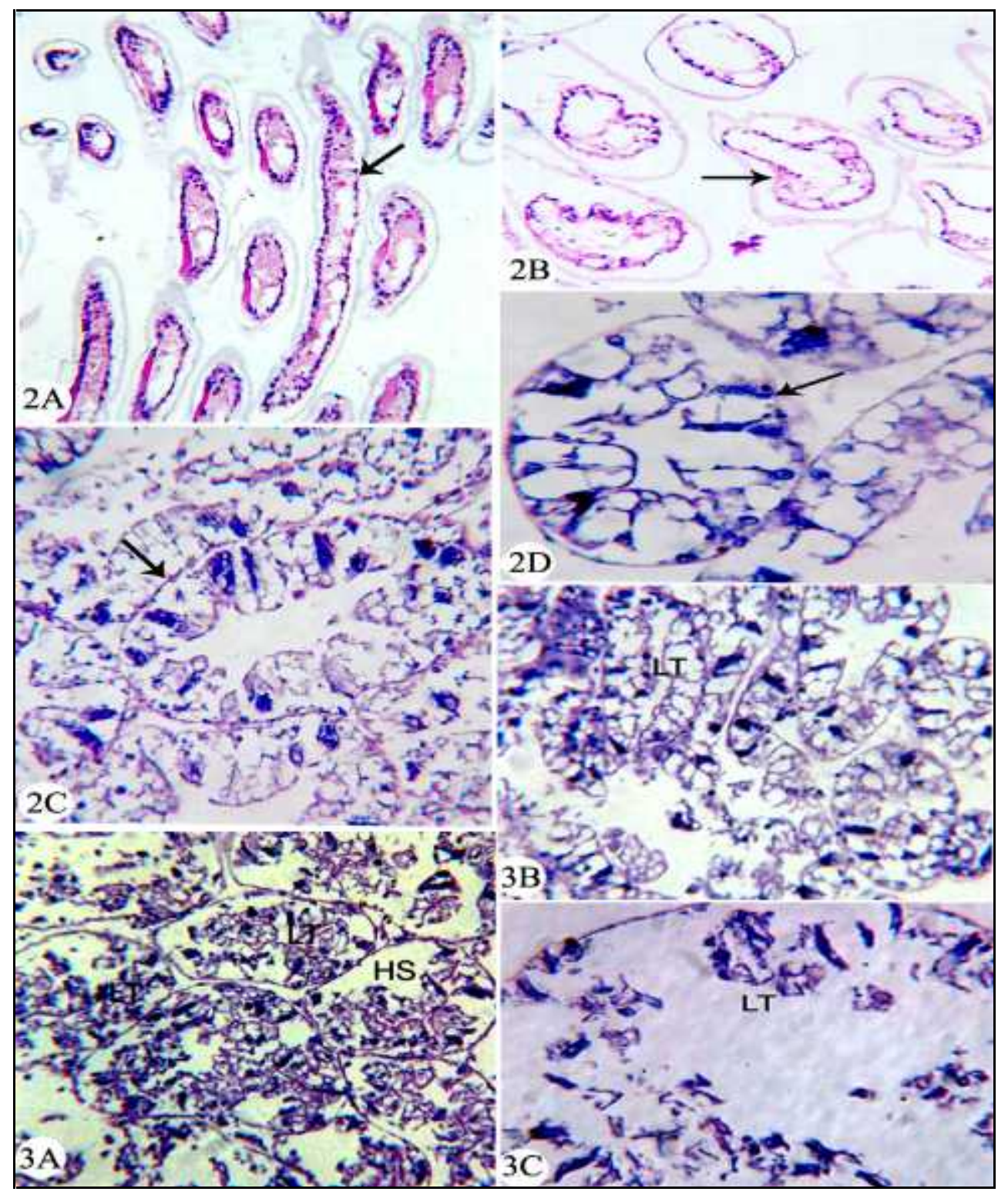

Fig. 2: Light micrographs of paraffin sections (A) normal and (B,C,D) WSSV-infected lymphoid organs of $P$. clarkii stained with H\&E showing general features of normal and WSSV-infected lymphoid organs surrounded by capsules containing antennal tubules embedded in connective tissue (arrows). (2A: X40; 2B: X100; 2C, D: X400). Fig. 3: Light micrograph showing antennal tubules of WSSV-infected crayfish investigated parts from antennal capsule, that project inwards and partitioned lymphoid organ into lymphoid tubules, each showing patent lumen. LT: lymphoid tubules, HS: haemal sinus. (A) Stomach, (B) Gut, (C) Hepato-pancreas. (3A, B: X100; 3C: X400). 

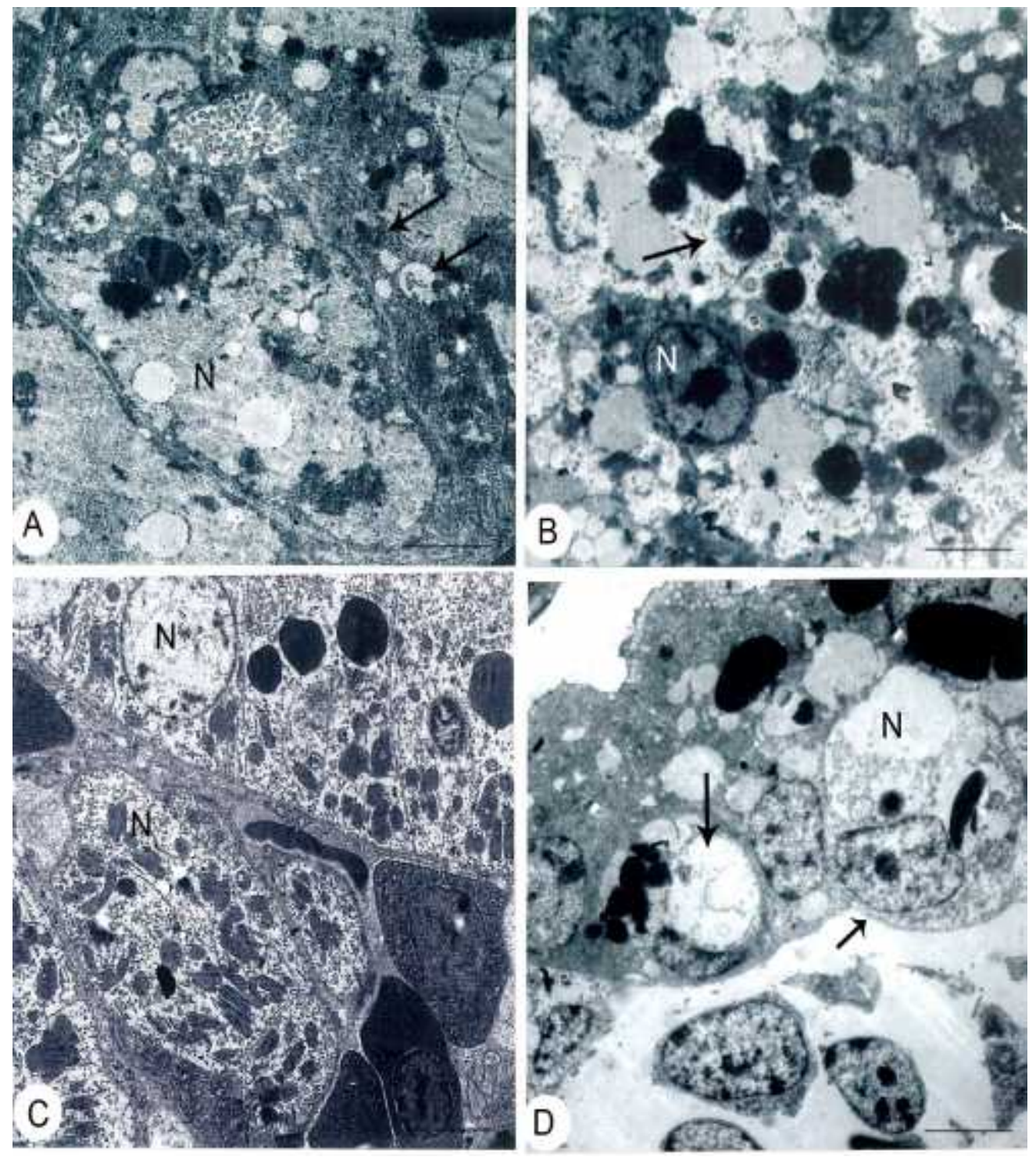

Fig. 4: Electron micrograph of P. clarkii hemocytes. (A) Large granule hemocyte showing intensely stained granules (arrows). Note bundles of microtubules (B) running parallel just beneath plasma membrane (arrows). Light micrograph of cuticle epidermis from WSSVinfected crayfish P. clarkii. (C) Arrows indicate hypertrophied nuclei under cuticle. Arrowheads indicate normal nuclei (D). A,C: X 800; B,D: X1000 


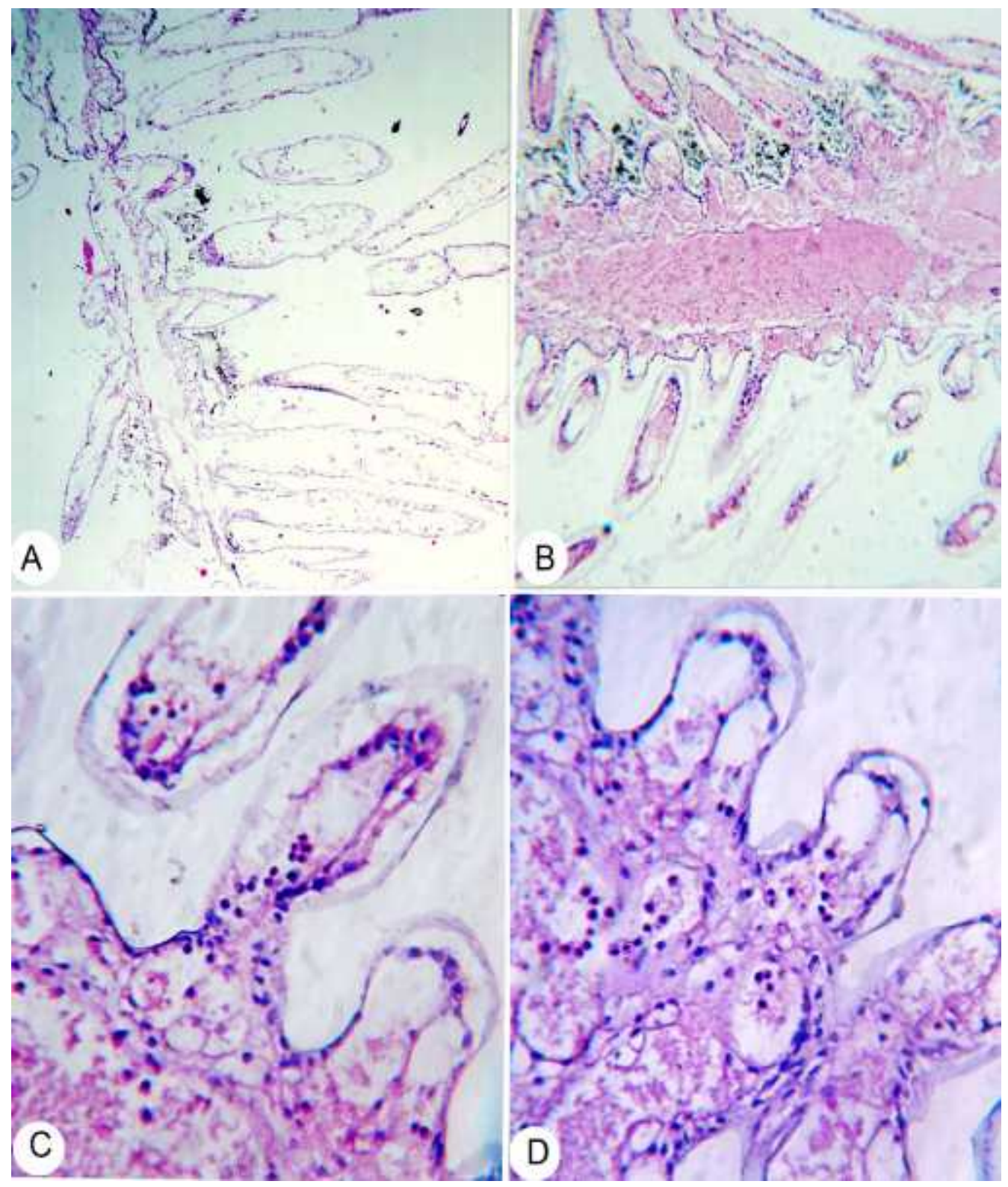

Fig. 5: Light micrograph of gill tissue of (A) non-infected, (B,C,D) WSSV-infected crayfish $P$. clarkii showing densely basophilic inclusion distinct from the nuclei. (A: X40; B: X100; C,D: X 400). 

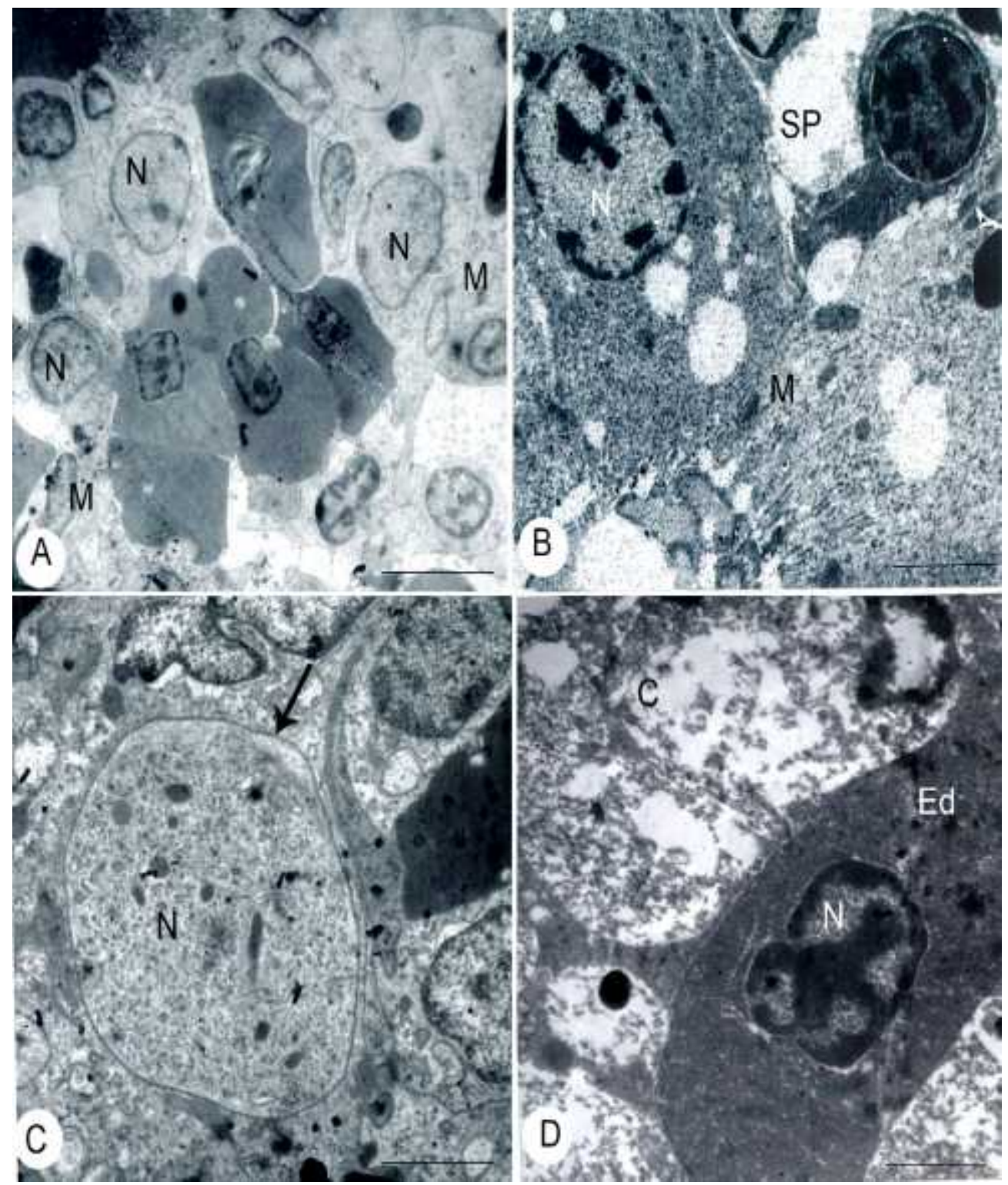

Fig. 6: Ultrastructure of gill cells by electron microscopy (A) Gill of control crayfish. Cutin, C; abundant mitochondria, M. X800 (B) Gill cell of control crayfish. Microvilli, M; Sp, space of cutin \& mitochondria. X900 (C) Gill cell of infected crayfish. Note deciduous microvilli and vacuole between cutin and epithelium (arrows). X900 (D) Gill cell of infected crayfish. Note damaged cutin membrane $(\mathrm{C})$ thin cytoplasm, reduced organelles and electron dense deposits (Ed). X1000 


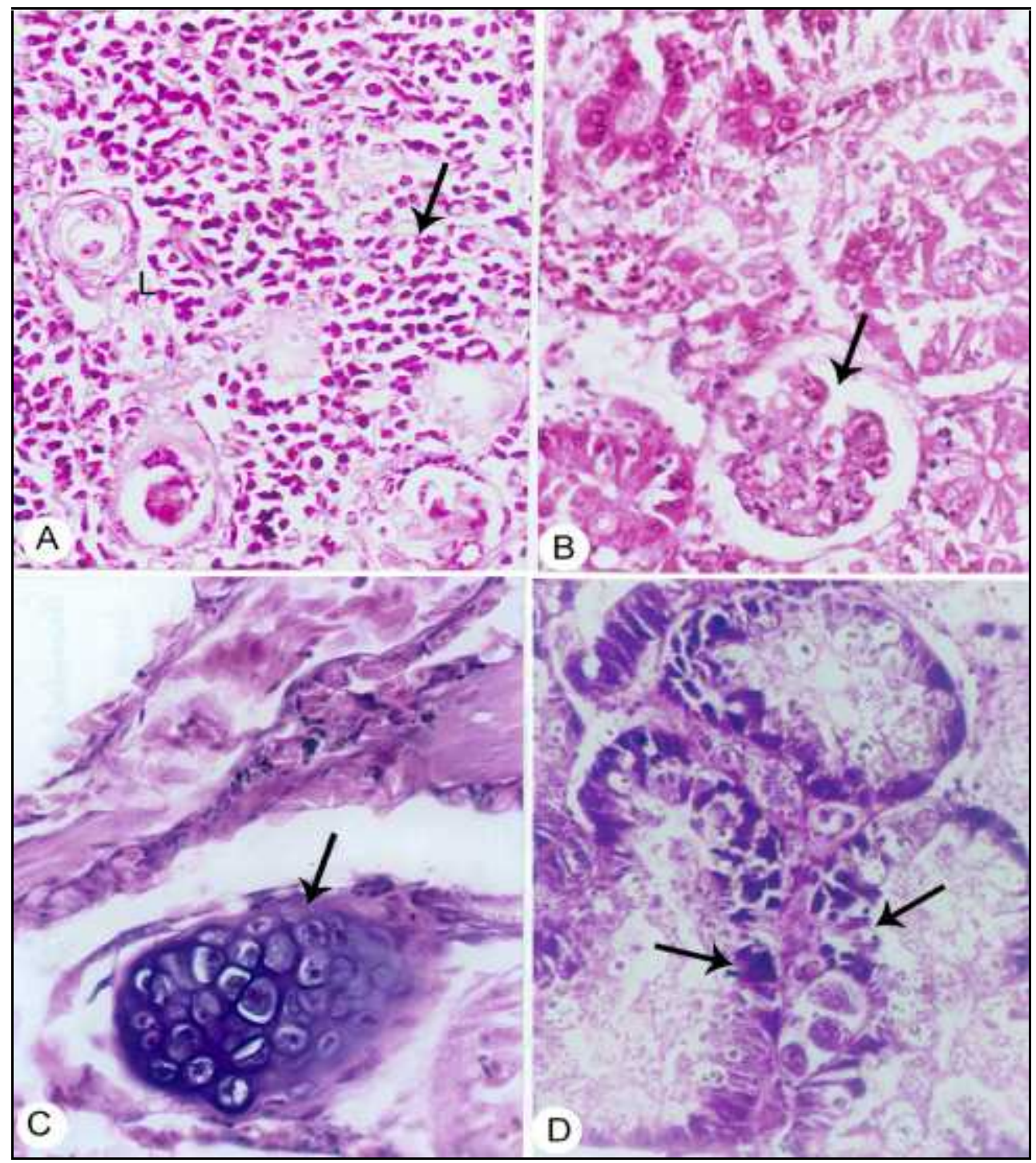

Fig. 7: Light micrograph of lymphoid organ of WSSV-infected crayfish, P. clarkii. (A) Early stage of infection showing normal tubule at top with lumen marked (L). Surrounding tubules are occluded; nuclei hypertrophied and cells highly vacuolated (arrows). X40 (B) Also, present (arrows) densely staining basophilic inclusions. X100 (C) Late stage of infection showing increased vacuolation and extensive necrosis (arrows). X400 (D) tubule at bottom with lumen marked (L) shows considerable cellular necrosis (arrows). X400. 


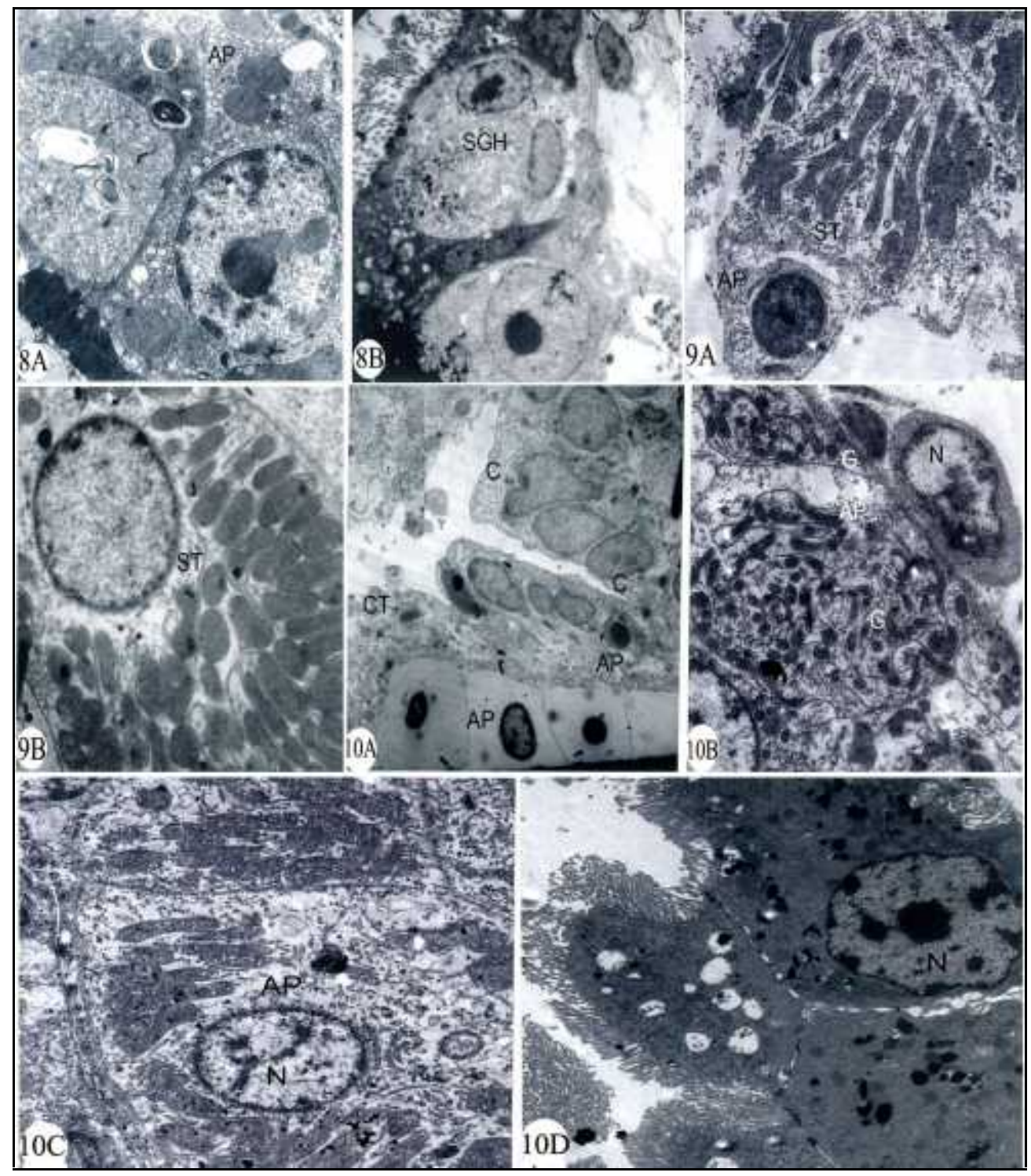

Fig. 8: Light micrographs of WSSV-infected lymphoid organ showing a large number of small granular hematocytes (SGH) surrounding apoptotic (AP) cells, identified as stromal cell (St) (A). (B) Electron micrograph of lymphoid spheroid type 1, showing a group of degranulated small granular hemocytes (SGH) surrounding a stromal cell (St). X1000 Fig. 9: Electron micrograph of lymphoid spheroid type 2, showing increasing number of heterophilic $(\mathrm{H})$ and apoptotic cells (AP) in spheroid. X1000 Fig. 10: (A,B) Electron micrograph of connective tissue from ventral part of crayfish cephalothorax showing highly mature granular cells $(\mathrm{G})$ with large electron dense granules. $\mathrm{C}$, cuticle; $\mathrm{Ct}$, connective tissue. (C, D) Electron micro-graph of lymphoid spheroid type 3, showing vacuolized apoptotic (AP) in entire spheroid. X1000 